\title{
Constitutionalism and Populism: National Political Integration and Global Legal Integration
}

DOI:

10.1017/S1752971919000186

\section{Document Version}

Accepted author manuscript

Link to publication record in Manchester Research Explorer

\section{Citation for published version (APA):}

Thornhill, C. (2019). Constitutionalism and Populism: National Political Integration and Global Legal Integration. International Theory, 12(1), 1. https://doi.org/10.1017/S1752971919000186

\section{Published in:}

International Theory

\section{Citing this paper}

Please note that where the full-text provided on Manchester Research Explorer is the Author Accepted Manuscript or Proof version this may differ from the final Published version. If citing, it is advised that you check and use the publisher's definitive version.

\section{General rights}

Copyright and moral rights for the publications made accessible in the Research Explorer are retained by the authors and/or other copyright owners and it is a condition of accessing publications that users recognise and abide by the legal requirements associated with these rights.

\section{Takedown policy}

If you believe that this document breaches copyright please refer to the University of Manchester's Takedown Procedures [http://man.ac.uk/04Y6Bo] or contact uml.scholarlycommunications@manchester.ac.uk providing relevant details, so we can investigate your claim.

\section{OPEN ACCESS}




\section{Constitutionalism and Populism: National political integration and global legal integration}

\section{Introduction}

In recent years, many societies have developed political systems that project their legitimacy in opposition to the corpus of global legal norms, which emerged after 1945 and was consolidated from the 1980 s onwards. ${ }^{1}$ In particular, many national political systems are now characterized by a backlash against international human rights law, and many governments deny that such law is authorized to determine the functions of national institutions, especially in domestic affairs. Of course, this is not a novel occurrence. Opposition to the domestic force of international norms can be found at many junctures in post-1945 history. ${ }^{2}$ In recent years, however, hostility to global legal norms has become a central plank in a distinctive pattern of neo-nationalist government, visible in different regions of the globe. The most salient example of this type of government is seen in the USA. A different example is found in the UK, where the ruling Conservative Party is frequently dismissive of globally authoritative normative principles; this formed important background to the Brexit referendum of 2016. Other examples in Europe can be found in Poland and Hungary, where government policies possess a strong anti-internationalist hue. ${ }^{3}$ This tendency is also widespread in Latin America, where, at different points on the left/right spectrum, governments have become established in Venezuela, Bolivia and Brazil, and appear to be

\footnotetext{
I am grateful to Guilherme de Azevedo, Carina Calabria, Atina Krajewska and Rafael Valim for important discussions during the writing of this article. I also wish to thank two anonymous reviewers for International Theory, whose highly insightful comments prompted me to revise some aspects of the article and to strengthen its core claims.

1 This legal order was established in stages, notably in the UN Charter; the UN Universal Declaration of Human Rights (1948); the International Covenants of 1966; human rights systems in Europe, Latin America and Africa; the Rome Statute of 1998.

2 An early example is the controversy in the USA about international human rights law in the 1950s, culminating in the proposed Bricker Amendment. See L. Henkin, 'US Ratification of Human Rights Conventions:

The Ghost of Senator Bricker', 89(2) American Journal of International Law (1995).

${ }^{3}$ See chapters by Gábor Halmai and Wojciech Sidurski in M.A. Graber, S. Levinson and M. Tushnet (eds), Constitutional Democracy in Crisis?(2018).
} 
taking shape in Colombia, which define their legitimacy in terms that diminish the standing of international norms.

Across case-to-case variations, governments of this anti-internationalist or neo-nationalist type contain the following features. First, they claim that governmental legitimacy depends on direct expressions of national sovereignty and national citizenship, which are viewed as diluted by international normative constraints, especially those attached to human rights law. ${ }^{4}$ Second, they strengthen governmental institutions authorized through direct appeals to national populations, and they diminish the countervailing powers vested in institutions whose position is bolstered by international norms. Consequently, they normally weaken judicial institutions, and, above all, they reduce the impact of global norms mediated through national judiciaries. ${ }^{5}$ In addition, third, they assume legitimacy by claiming a strong identitarian basis in society. Especially in Europe, governments marked by hostility to legal globalism express the presumption that the people has one will and one set of interests, which are fragmented by global norms, and which must be immediately enacted by national politicians. In each respect, governments of this type attach legitimational primacy to a dual concept of sovereignty - they insist on the external sovereignty of national political institutions and the internal sovereignty of the national people as the ineliminable foundations of legitimate political order.

\footnotetext{
${ }^{4}$ This can be seen in criticism of the European Court of Human Rights and plans for a British Bill of Rights in the UK, in Donald Trump's strictures against the International Criminal Court, in Venezuela's withdrawal from the jurisdiction of the Inter-American Court of Human Rights (IACtHR).

${ }^{5}$ The political impetus behind Trump's judicial appointments is widely observed. See analysis of the politicization of judicial appointments in Brazil at http://www.iconnectblog.com/2017/02/brazils-increasingly-politicized-supremecourt/. On Poland, see R. Grzeszczak and I.P. Karolewski, 'The Rule of Law Crisis in Poland: A New Chapter', at https://verfassungsblog.de/the-rule-of-law-crisis-in-poland-a-new-chapter/. Ivan Duque, elected President of Colombia in 2018, campaigned on the pledge to dismantle the Constitutional Court, which was historically very open to international law.
} 
In key respects, present-day governments with these features can be grouped together as examples of political populism. Populism is of course a notoriously inexact term, and it covers patterns of government with greatly varying policy emphases. Generally, however, the overlapping residue that defines different populist governments and movements is that they attach the legitimacy of political order to the direct and unrestrained enactment of the popular will. In populist politics, people are invited to imagine themselves as constantly engaged in the exercise of constituent power, ${ }^{6}$ and government is perceived as legitimate if the popular will acts as a live political force in the state, assuming higher authority than constituted institutions and institutional actors that usually mediate popular interests into legislative form. ${ }^{7}$ This conception of popular agency means that, under populist rule, formal legal and organizational structures for facilitating political representation lose purchase, and elections acquire strongly plebiscitary dimensions. Moreover, it means that governments placed in power by popular mobilization possess, in principle, a mandate for authoritarian exercise of political power. It means, above all, that the position of international legal norms in domestic constitutional law appears distinctively illegitimate. These characteristics are evident in the primary contemporary examples of anti-internationalist or neo-nationalist government. ${ }^{8}$

Theoretical discussions of populism, both historical and contemporary, revolve around a series of stock positions. Conventionally, political analysts examined populism by addressing

\footnotetext{
${ }^{6}$ For the basis of this characterization see P. Blokker, 'Varieties of Populist Constitutionalism: The Transnational Dimension', 20 German Law Journal (2019) 333-34. This article relates to my own analysis in C. Thornhill, 'Rights and Constituent Power in the Global Constitution', 10(3) International Journal of Law in Context (2014). See also P. Norris and R. Inglehart, Cultural Backlash. Trump, Brexit and Authoritarian Populism (2019) at 65, 247.

7 Obvious examples are the semi-plebiscitary aspects of constitutional law evident in Venezuela and the UK. Some articles of the Venezuelan constitution of 1999 (especially Arts 6, 62, 70, and 184) are intended to preserve a live constituent power in the state.

${ }^{8}$ Most states with neo-nationalist governments have a long history of populism. This does not apply to the UK, but, since 2016, both main parties in the UK have populist wings, strongly committed to discourses of national sovereignty. In fact, the UK can now be seen as one of the purest examples of populist rule, as the current government legitimates itself to a large degree by discrediting formal procedures for political representation and by appealing directly to the popular will.
} 
the electoral appeal of populist politicians. ${ }^{9}$ Less frequently, sociologists have attempted to explain the social preconditions of populism. ${ }^{10}$ Across these lines of analysis, different observers have tended to arrive at one convergent conclusion: most see populism as a governmental model that thrives because of inner contradictions in constitutional democracy, ${ }^{11}$ and which can always evolve, as an organic parasite, ${ }^{12}$ in societies committed to democratic government. ${ }^{13}$ Indeed, some observers see aspects of populism, especially in its emphatic assertion of popular sovereignty, as forming a potentially salutary corrective to formalist elements in representative government. ${ }^{14}$ More recently, populism has become an object of analysis amongst constitutional theorists, who have placed greater emphasis on its normative implications. Such debate has a longer tradition in the USA, where, in the 1980s and 1990s, populist constitutionalism was advocated as an alternative to court-crafted constitutionalism. ${ }^{15}$ However, populism is now examined across the globe as a distinct pattern of constitutionalism. ${ }^{16}$ At core, constitutional theorists still echo principles in earlier lines of inquiry, and they also identify a close relation between populism and constitutional democracy. In addressing this relation, some constitutionalists emphasize the deep tension

\footnotetext{
${ }^{9}$ See P. Ignazi, Extreme Right Parties in Western Europe (2002), at 34; C. Mudde, The Ideology of The Extreme Right (2002), at 15; S. L.de Lange, 'A New Winning Formula? The Programmatic Appeal of the Far Right', 13(4) Party Politics (2007) 430.

${ }^{10}$ See G. Germani, Authoritarianism, Fascism and National Populism (1978), at 218; F. Weffort and A. Quijano, Populismo, marginalización y dependencia. Ensayos de interpretación sociológica (1973), at 113; C. M. Vilas, 'Latin America Populism: A Structural Approach', 56(4) Science and Society (1992); R.S. Jansen, 'Populist Mobilization: A New Theoretical Approach to Populism', 29(2) Sociological Theory (2011) 90.

${ }^{11}$ For summary see K. Abts and S. Rummens, 'Populism versus Democracy', 55 Political Studies (2007) 411.

12 T. Fournier, From Rhetoric to Action - A Constitutional Analysis of Populism. EUI Department of Law Research Paper No. 2018/08, at 1.

${ }^{13}$ See J.-W. Müller, What is Populism? (2017), at 20; S. Issacharoff, 'Populism versus Democratic Governance' in M. A. Graber, S. Levinson and M. Tushnet (eds), Constitutional Democracy in Crisis? (2018), 453; B. Cannon, Hugo Chávez and the Bolivian Revolution. Populism and Democracy in the Globalized Age (2009), at 77; F. Panizza, 'Introduction: Populism and the Mirror of Democracy' in F. Panizza (ed), Populism and the Mirror of Democracy (2005), 29; B. Arditi, 'Populism as an Internal Periphery' in F. Panizza (ed), Populism and the Mirror of Democracy (2005), 93; T. Ginsburg and A. Z. Huq, How to Save a Constitutional Democracy (2018).

${ }^{14}$ E. Laclau, Politics and Ideology. Marxist Theory. Capitalism - Fascism - Populism (1977), at 196-7; T. Tännsjö, Populist Democracy. A Defence (1992), at 61; M. Canovan, 'Trust the People! Populism and the Two Faces of Democracy', 47(1) Political Studies (1999) 14; Norris and Inglehart, supra note 6 at 22.

${ }^{15}$ M. Tushnet, Taking the Constitution Away from the Courts (1997); R. D. Parker, "Here, the People Rule": A Constitutional Populist Manifesto', 27(3) Valparaiso University Law Review (1993).

16 P. Blokker, 'Populist Constitutionalism' in C. de la Torre (ed), Routledge Handbook of Global Populism (2018); P. Blokker, New Democracies in Crisis? A Comparative Constitutional Study of the Crech Republic, Hungary, Poland, Romania and Slovakia (2015), at 41; L. Corrias, 'Populism in a Constitutional Key: Constituent Power, Popular Sovereignty and Constitutional Identity', 12 European Constitutional Law Review (2016) 8.
} 
between populist and constitutional-democratic concepts of legitimacy. ${ }^{17}$ Nonetheless, others indicate that populism may generate benefits for constitutional culture, as it condemns, and demands refection upon, the frequent erosion of democratic participation under constitutional rule. ${ }^{18}$ These views extend the theoretical consensus that populism is part of democracy, to be seen as the result of tensions between the political and participatory and the legal-normative and procedural aspects of democratic constitutional rule. ${ }^{19}$ In each perspective, democracy appears as a polity type whose legitimacy results from acts of citizens exercising popular sovereignty, and such sovereignty often conflicts with formal-normative provisions that support representative government. The normative essence of sovereignty, thus, can always stimulate populist impulses, and democracy is ultimately legitimated by the degree to which it translates expressions of sovereign will formation, which may include populist impulses, into constitutionally ordered patterns of representation. ${ }^{20}$ As a result, the hostility to international norms in populist government is explained as one expression of the broader populist aversion to strictly constitutional aspects of democratic government, and it reflects a vital impetus to popular sovereignty that cannot be eradicated from democracy. ${ }^{21}$

This article engages critically with existing analysis of populism, and it critically reassesses the underlying claim that populism results from contradictions in democratic constitutionalism. It argues that, in addressing this point, existing analysis displays both

\footnotetext{
${ }_{17}$ A. R. Brewer-Carías, 'Judicial Review in Venezuela', 45(2) Duquesne Law Review (2007) 440; D. Landau, 'Populist Constitutions', 85 University of Chicago Law Review (2016); N. Urbinati, 'Democracy and Populism', 5(1) Constellations (1998).

${ }^{18}$ G. Zaccaria, 'The People and Populism', 31(1) Ratio Juris (2018) 44; C. Pinelli, 'The Populist Challenge to Constitutional Democracy', 7 European Constitutional Law Review (2011) 15; K. Möller, 'Invocatio Populi. Autoritärer und demokratischer Populismus', 45 Leviathan, Sonderband 34 (2017) 247; Blokker supra note 6.

${ }^{19}$ See classical analysis in P. Worsley, 'The Concept of Populism' in G. Ionescu and E. Gellner (eds), Populism. Its Meanings and National Characteristics (1969), 246-47. See also Y. Mény and Y. Surel, 'The Constitutive Ambiguity of Populism' in Y. Mény and Y. Surel (eds), Democracies and the Populist Challenge (2002), 7-8; 'T. Akkerman, 'Populism and Democracy: Challenge or Pathology', 38 Acta Politica (2003) 155; Blokker, supra note 16, at 37; Fournier, supra note 12 , at 15 .

${ }^{20}$ See M. Canovan, 'Taking Politics to the People: Populism as the Ideology of Democracy' in Y. Mény and Y. Surel (eds), Democracies and the Populist Challenge (2002), 43

${ }^{21}$ Blokker supra note 6; Blokker, supra note 16, at 6.
} 
explanatory and normative shortcomings. At the explanatory level, the deepest deficiency in existing analysis is that it lacks broad sociological penetration, and it does not establish why political expectations attached to democracy provide motivations and legitimacy for populism, in so many different settings. In particular, it does not subject democracy itself to critical scrutiny: although democracy appears as the cause of populism, the possibility that democratic norms, or their social construction, may have some responsibility for populism is not addressed. Partly for this reason, further, existing analysis does not explain why propensities for populism are linked to the rising power of global legal norms, or why the attack on global law is so fundamental to populism. At the normative level, such analysis is deficient, primarily, because it offers an insufficiently robust critique of populism. Such analysis presupposes, simply, that democracy is a political order legitimated by popular sovereign acts. As a result, it is forced by its normative focus on popular agency to impute a certain degree of legitimacy to populism.

Against this background, this article proposes a new critical model to explain populism, which is centred on a distinctive reconstruction of democracy itself.

This model implies, first, that populism is induced, in part, by the fact that the constitutional terms in which democracy is envisaged are sociologically ill-constructed. In this respect, this article mirrors the recent shift towards analysis of populism in constitutional inquiry. ${ }^{22}$ However, it claims that constitutional inquiry is partly responsible for populism. Doctrines of constitutional democracy derive governmental legitimacy from classical political subjects notably, popular sovereignty, sovereign state institutions, national citizenship - that cannot provide an adequate explanation of democracy, yet which offer manifest legitimacy for

\footnotetext{
22 See Zaccaria supra note 18.
} 
populist movements. ${ }^{23}$ Constitutional theorists normally argue that democracy must have a national, or at least popular, foundation, reflecting classical ideas of popular sovereignty, ${ }^{24}$ and they are frequently dismissive of global patterns of rights-based norm formation. ${ }^{25}$ Such assumptions, it is claimed here, adversely pre-determine our understanding of populism, and they exacerbate tendencies towards populism. ${ }^{26}$ This model implies, second, that the misunderstanding of national democracy that gives rise to populism is linked to a still deeper misunderstanding, which also reflects deficiencies in constitutional theory: that is, both populism and more conventional constitutionalist outlooks misunderstand nationhood itself. ${ }^{27}$ Central to populism is the conviction that national peoples existed as sovereign political actors before the system of global legal norms had been created, and they can always revert to a position in which they reacquire - or, take back - their original sovereign powers. This idea is clearly related to core principles in classical constitutionalism, which described the source of legitimate law as the people in sovereign form, standing before and authorizing all binding legal norms. ${ }^{28}$ It is shown here, however, that these ideas grow from a deep fiction in constitutional thinking.

\footnotetext{
23 See for example Canovan supra note 20, at 33.

${ }^{24}$ See E.-J. Sieyès, Qu'est-ce que le tiers-état? (1839 [1789]); C. Schmitt, Verfassungslehre (1928); D. Miller, On Nationality (1995); D. Grimm, Die Zukunft der Verfassung II. Auswirkungen von Europäisierung und Globalisierung (2012); M. Loughlin, Foundations of Public Law (2010).

${ }^{25}$ J. Waldron, 'The Core of the Case against Judicial Review', 115 The Yale Law Journal (2006); R. Bellamy, Political Constitutionalism. A Republican Defence of the Constitutionality of Democracy (2007); G. Webber, The Negotiable Constitution. On The Limitation of Rights (2009).

${ }^{26}$ Even more cosmopolitan constitutional theories persist in imagining that the prototype of a legitimate constitution is the national constitution, constructed around the simple active engagement of sovereign citizens. See J. Habermas, 'Zur Prinzipienkonkurrenz von Bürgergleichheit und Staatengleichheit im supranationalen Gemeinwesen. Eine Notiz aus Anlass der Frage nach der Legitimität der ungleichen Repräsentation der Bürger im Europäischen Parlament', 53(2) Der Staat 53(2) (2014); H. Brunkhorst, Critical Theory of Legal Revolutions - Evolutionary Perspectives (2014).

27 See as basis Germani's account of the nation as a society defined by (1) growing integration of marginal groups; (2) incorporation of marginal geographical areas; (3) acquisition of national loyalties and identifications by inhabitants; (4) high cultural and economic homogeneity; (5) effective full citizenship, with adult political participation: Germani, supra note 10, at 101.
} 
The model set out here seeks to show that national democracy always depends on a close articulation between national citizens and global norms. Quite generally, national democracy became a global reality in the last three decades through a set of integrational processes, tightly linked to the penetration of global norms in national societies, in which democratic government progressively detached itself from the core subjects imputed to democracy in constitutional theory. Democracy, therefore, is factually built upon a set of integrational processes that are not captured by the diction of democratic constitutionalism, and conflict between democracy as subjective normative expectation and democracy as objective integrational process is always a potent risk in globally articulated democratic polities. Under certain conjunctures, however, the processes of integration, on which both democracy depends, conflict sharply with the normative constructions that underpin constitutionaldemocratic ideals, and such constructions can easily be mobilized against the sociointegrational foundations of democracy itself. Normally, such conflict becomes acute in political settings, in which, for whatever cause, crises or challenges in the international domain possess the potential to discredit global norms. Such settings are often advantageous for populist movements; populism commonly appears in such contexts as a type of political movement or government in which leadership groups are able to mobilize electorates against global norms and institutions supported by international norms within national societies. ${ }^{29}$ They manage this, typically, by encouraging national populations to identify immediately with the roles assigned to them in classical understandings of constitutional democracy - that is, to imagine themselves as sovereign national peoples, or national constituent actors. Assumption of such roles, however, constantly intensifies the latent conflict between democracy as normative expectation and democracy as integrational reality at the core of

\footnotetext{
${ }^{29}$ Generally, we can see that populism has experienced an upsurge in the last decade because certain factors appearing in the global domain - financial crises, erosion of national welfare regimes, unregulated investment policies, perhaps mass immigration - are deployed as pretexts for an assault on norms of international provenance in national societies.
} 
contemporary politics. If radicalized, the assumption of such roles allows the norm of democracy to destroy national democracy as integrational reality, which is deeply reliant on global norms. Populism, in short, is closely conditioned by the false construction of democracy in constitutional theory. It tends to take shape where this construction is allowed to contradict the integrational form in which democracy usually becomes reality.

The model for examining populism proposed here is conceived as an ideal-typical construct. It does not claim to elucidate hard causal connections that lead to populism. Indeed, this model has clear limits. Distinct patterns of democratic formation in national societies only broadly align to the integrational model of democracy set out here, and they contain deep variations. Further, populism is brought into life by a range of inner-societal and external determinants, which elude mono-focal analysis. As discussed below, further, norms that regulate some spheres of global exchange can manifestly obstruct democracy. ${ }^{30}$ Nonetheless, this model allows us to understand the expectations inherent in democracy that stimulate neonationalist populism. Moreover, it enables us to identify the legal conjunctures that favour populism: such conjunctures normally reflect disalignment between the integrational and the normative premises of democracy. It also allows us to appreciate reasons for the hostility to global norms in contemporary populism.

Overall, this article offers a new constitutionalist approach to populist anti-globalism. It shows that democratic constitutionalism contains concepts that both impel (at the normative level) and sometimes also impede (at the functional-integrational level) the formation of society on a national democratic design. Only if constitutional theory takes care to identify

\footnotetext{
30 See p. XXX below.
} 
the functional processes that bring reality to its normative constructs can it contribute to the actual preservation of democracy.

\section{Constitutional legitimacy and the formation of national society}

Citizenship, national membership, and constitutional law

At a primary level, constitutionalism is centred around a conceptual subject that has contributed to the formation of democratic nationhood both through its normative and its functional-integrational impact. This subject is embedded in the constitutional construct of the citizen. In this construct, constitutional reflection first took shape as a description of society capable of projecting normative claims in categories that reinforced the functional preconditions their own realization, so that early constitutional thought expressed norms that stimulated the processes of integration that allowed subjects implied in these norms to become real. To this degree, the primary construct of constitutionalism articulated a real subject, which created both normative and objective conditions required to sustain democracy.

In parts of Europe and other states under European influence, the concept of the citizen had, by circa 1800 , converged around three principles, each of which proved fundamental to the emergence both of national democracies and of national societies. It expressed the assumption that persons in society must possess (a) rights to occupy physical space within a demarcated societal territory, usually with rights to own land and property; (b) certain procedural rights, especially rights regarding legal protection, formal equality, and personal integrity before the law; (c) rights to participate, in notionally equal fashion, in procedures that produce the laws that shape the life of the society in question. Such principles only gradually acquired meaningful social purchase, and their impact on societal structure usually 
took at least a century to become fully palpable. However, from approximately 1800 onwards, the construction of the citizen as social subject had tangible material consequences for the form of society.

The first outcome of these principles was that societies configured around citizenship evolved as increasingly integrated systems of interaction, in which relations between persons were structured in legal form. From the outset, the rise of citizenship meant that social organization was detached from personalized patterns of coercion, typically those exemplified in European feudalism and analogues to feudalism outside Europe, in which personal obligations were dictated by status hierarchies based in land ownership and tenure. ${ }^{31}$ Gradually, the concept of the citizen established the expectation that persons in society were subject to the same normative rules, supported by claims to general validity, such that social action was increasingly controlled by uniform legal principles. The principle that social obligations need to reflect norms with general validity was already implied, inchoately, in patterns of social organization that characterized the territorial states of early modern Europe. In fact, the mode of territorially delineated governance usually rather crudely defined as 'absolutism' was centred in a rough pre-construction of national citizenship, as it severed social obligations from variable personal power, it placed all social actors under uniform higher laws, and it defined the legitimacy of the political system in society in common secular categories. ${ }^{32}$ By the late eighteenth century, however, the expectation that interpersonal obligations should be determined by general laws had been strengthened in much of Europe, and few societal

\footnotetext{
${ }^{31}$ In feudal systems, lords held personal rights over subjects or vassals because they held rights over the land on which these subjects lived. See O. Brunner, Land und Herrschaft. Grundfragen der territorialen Verfassungsgeschichte Südostdeutschlands im Mittelalter, second edition (1942), at 368; T.N. Bisson, The Crisis of the Twelfth Century. Power, Lordship, and the Origins of European Government (2009) at 14.

${ }^{32}$ R. Koselleck, Kritik und Krise. Eine Studie zur Pathogenese der bürgerlichen Welt (1973[1959]).
} 
domains were not in some way subject to centralized legal norms. ${ }^{33}$ Increasingly, further, the expectation that law must be generally valid was accompanied by the expectation that it had to be founded in general interests or rational prerogatives, shared by all members of society. ${ }^{34}$ On this basis, implicitly, society itself became a system of public order, in which interaction between persons was shaped by legal principles of a generally accepted nature.

In consequence, further, societies configured around norms of citizenship acquired a progressively fixed geographical form, and their material-territorial structure was defined through expectations implied in citizenship. Citizenship contains the central implication that the shared legal obligations to which it gives rise apply to persons in one physical territory, and, as they presuppose general acceptance, the same obligations do not necessarily apply to persons situated outside this territory. To this degree, citizenship formed the essential focus of the modern nation state, and the identification of a state with a specific socio-territorial space originated in the fact that institutions imposing duties and obligations were underpinned by principles of citizenship. In this respect, the basic substance of nationhood lies, not solely in the simple physical territory of the nation, but rather in the fact that this territory is a legally constituted social domain, whose inhabitants are bound by obligations of an intrinsically public character.

On both counts, the concept of citizenship underscores the modern nation. ${ }^{35}$ National society was initially produced by processes of integration driven by citizenship, in which social order was formed through the emergence of laws with implicit claims to public authority. However, the greatest significance of citizenship in shaping modern society is visible in society's

\footnotetext{
${ }^{33}$ In much of Europe, the later eighteenth century witnessed large-scale processes of codification and concerted attempts to reduce the judicial autonomy of estates and guilds.

${ }^{34}$ This was usually reflected in the importance of natural law as a basis for law codes. See S. Breuer, Sozialgeschichte des Naturrechts (1983), at 199.

${ }^{35}$ D. Gosewinkel, Schutz und Freibeit? Staatsbürgerschaft in Europa im 20. und 21. Jabrbundert (2016), at 37.
} 
political dimension, and it was as the pivotal term in early constitutional doctrine that the subject of the citizen impacted most transformatively on societal form.

The underlying design of the modern national political system was created in the early constitutional revolutions of the eighteenth century in the British colonies in America and in France, and this design clearly reflected the growing importance of citizenship norms. ${ }^{36}$ The significance of citizenship was expressed - initially - in the fact that, prior to the popular revolutions from the 1770 s to the 1790 s, it was increasingly presumed that the political order of a society ought to be defined by higher-order laws, recognized by all people as having a collective, public foundation. ${ }^{37}$ In consequence, the legitimate political system was already envisioned as a national political system, ordered under laws acknowledged by and applied to all members of national society. To this degree, the emergent political system of early national societies transposed into coercive form the basic expectations expressed in the concept of citizenship. During the revolutionary decades, then, citizenship became an emphatic term for constructing political legitimacy. At a general level, ideas of citizenship promoted revolutionary theories of popular sovereignty, implying that the political system obtains legitimacy if its legal order is willed into being by collective decisions of citizens, acting in the form of a nation, or a people. In this respect, the national people was imagined as a self-legislating sovereign actor, and legitimate laws were observed as manifestations of popular sovereignty. More specifically, ideas of citizenship were phrased in clearly constitutional concepts, especially in the revolutionary theory of constituent power. ${ }^{38}$ Constitutional doctrines in revolutionary Europe translated the theory of popular sovereignty

\footnotetext{
36 See D. Bradburn, The Citizenship Revolution. Politics and the Creation of the American Union 1774-1804 (2009).

${ }^{37}$ In pre-revolutionary France, a doctrine of 'fundamental laws' was already accepted. See R. Bickart, Les Parlements et la notion de la souverainété nationale au XVIIIe siècle (1932), at 43, 73. In pre-revolutionary America, the law courts were already viewed as custodians of higher laws. See N.B. Williams, 'Independent Judiciary Born in Colonial Virginia', 24 Journal of the American Judicature Society (1940).

${ }^{38}$ See for paradigmatic expression of this Sieyès, supra note 24. See also J. Madison, A. Hamilton and J. Jay (1987) The Federalist Papers (1987 [1787-88]), at 327.
} 
into the claim that the people exercises its sovereignty as a constituent body, standing prior to all ordinary law, defining the primary norms which give legitimacy to the polity and by which actors in the polity are bound. In this theory, obligations arising from the constituent power integrate all society in a common sovereign national legal-political order. ${ }^{39}$ On this basis, the modern political system was envisaged as an institutional order that originated in constitutional commitments of sovereign national citizens - in which citizens acted as the subjective authors of the laws that objectively determined their lives. In each respect, the concept of the citizen spelled out an original norm of constitutional immediacy between actors in national society and the national state, such that a direct constitutional nexus between the state and citizen, not subject to attenuation by intermediary persons or organizations, formed the foundation of the state's legitimacy and society's legal order. ${ }^{40}$

The constitutional principles resulting from citizenship in the eighteenth-century revolutions played a central role in imprinting a broad national democratic design on society, and the normative importance of citizenship in the revolutionary era reinforced earlier functionalintegrational implications of citizenship.

This can be seen in several ways.

First, these constitutional principles meant that the political system was able to assume generalized legitimacy for its functions, and it became possible for actors in the political system to insist that their laws possessed primary, decidedly public authority in all parts of society. It was repeatedly declared in the eighteenth-century revolutions that, as it was authorized by citizens, the political system of society had to be categorically separated from

\footnotetext{
${ }^{39}$ Grimm supra note 24.

${ }^{40}$ M. P. Fitzsimmons, From Artisan to Worker. Guilds, the French State, and the Organization of Labor, 1776-1821 (2010), at 11,118 .
} 
local - usually residually private or privilege-based - organs of coercion. ${ }^{41}$ As a result, political institutions acquired a distinctive hierarchical position in their relation to centres of power located outside the polity: for example, to organizations attached to localities, estates, or families. In turn, this meant that society as a whole began to converge, or to become focally centralized, around a clearly identifiable aggregate of political institutions, able to enforce political directives for society as whole. Norms articulated by constituent actors were also used to define the essential functions of public agents, which meant that public offices entailed the discharge of duties of a specific public nature, and they could not be traded as privileges or private goods. ${ }^{42}$ Together, these processes meant that political institutions acquired attributes of inner-societal sovereignty, and they exercised powers quite distinct from those vested in other associations. ${ }^{43}$

Over a longer period of time, second, these constitutional principles had the consequence that the capacity of public institutions for integrating actors across national society was extended. The fact that the state was constructed around an immediate legitimational nexus with persons (citizens) in society meant that the legitimacy of the state became increasingly contingent on direct interactions with individual agents. This also meant that a growing quantity of social exchanges was subject directly to political regulation, as interests of particular persons and particular groups acquired heightened political relevance. One result of these processes, in turn, was that state institutions required more revenue and more extensive instruments of fiscal extraction to perform regulatory functions, which further heightened the engagement of the state with single persons. ${ }^{44}$ The legitimational importance of citizenship

\footnotetext{
${ }^{41}$ See Sieyès, supra note 24.

42 On the early growth of administrative law after 1789 see R. Burdeau, Histoire du droit administratif (1995), at 65-66.

${ }^{43}$ See M. Weber, Wirtschaft und Gesellschaft. Grundriß der verstehenden Soziologie (1921/22), at 427.

${ }^{44}$ Early democratic revolutions had the result that the authority of public agencies increased rapidly and their regulatory, military and fiscal capacities were extended. See for example P. Cancik, Verwaltung und Öffentlichkeit in Preußen (2007); C. Church, Revolution and Red Tape. The French Ministerial Bureaucracy 1770-1850 (1981). The deepening
} 
almost invariably increased the societal penetration of public institutions, intensifying the immediacy of the lines of interaction between government and society.

Third, these constitutional principles triggered increased communication between the political system and persons in society, and social actors were more comprehensively incorporated in nationalized political roles and functions. ${ }^{45}$ The legitimational force of citizenship meant that actors in the political system usually constructed mechanisms to facilitate the participation of citizens in certain political responsibilities, especially in the production of legitimacy for the laws by which they were bound. In particular, this led to the consolidation of institutions intended to construct legitimacy in the form of collective consensus, and states legitimated by citizenship norms usually evolved institutions able to represent citizens directly to officeholders within the political system. ${ }^{46}$ At the same time, this led, almost immediately, to the proliferation of organizations later known as political parties, which served to transmit prerogatives in different spheres of society towards the political system, and so to authorize legislation through acts of concerted political mobilization. ${ }^{47}$ The latter process played a singularly important role in the consolidation of national societies on a fully national, integrated pattern. ${ }^{48}$

\footnotetext{
of enfranchisement in the nineteenth century led to the concomitant expansion of administrative organs. See Weber, supra note 43 , at 571 . The process of state expansion became especially palpable, in different countries, in the years around 1910. In many countries, for example Germany, the UK, the USA and Russia, this period saw the introduction of permanent income tax, so that public institutions were placed in immediate relation to particular subjects in society, and private variations in status were greatly weakened. See Y. Kotsonis, "Face-to-Face": The State, the Individual, and the Citizen in Russian Taxation, 1863-1917', 63(2) Slavic Review (2004) 225. The great leap forward in democratic enfranchisement then occurred in Europe during World War I, which led to a profound extension of public institutions and their extractive and mobilizational functions.

${ }^{45}$ See classical analysis in K.W. Deutsch, Nationalism and Social Communication. An Inquiry into the Foundations of Nationality, 2nd edition (1962).

${ }^{46}$ By 1848, most European states possessed rudimentary electoral franchises and representative assemblies.

${ }^{47}$ By circa 1800, loosely identifiable political parties existed in Britain, Sweden, France, and the USA. By 1900, political parties were instruments of political interest representation in most states.

${ }^{48}$ D. Caramani, The Nationalization of Politics. The Formation of National Electorates (2004).
} 
In each respect, the formation of modern national societies has its origins in a process of constitutional norm construction, in which members of national populations imagine themselves as distinctively defined political actors (citizens), able to authorize laws for society as a whole. On this foundation, national societies evolved as systems of integration, centred around legal and political institutions with sovereign powers, usually tending to assume at least some democratic emphases. ${ }^{49}$ Initially, most societies took the form of nations, defined by broad processes of integration, and of democracies, defined by broad processes of shared norm creation, as parts of the same structural-integrational process. As such, the normative and the functional elements of national society were, historically, integrally connected, and these elements were linked together in the core construct of constitutionalism - in the political subject of the citizen. The rise of constitutional law, which distilled concepts of citizenship into the theory of constituent power, was - initially - central both to the normative formation of society on a democratic pattern and to the functional construction of society as a system of national integration, able to sustain early patterns of democratic agency. In its basic elements, modern society was formed by constitutional subjects, in which citizenship imprinted a distinct integrational form on societal structure.

The antinomies of citizenship

Despite these deep connections between constitutional norms and socio-political integration, we can observe certain critical antinomies in the normative constructs that underlie nationaldemocratic societies. Indeed, the concepts of legitimacy around which democratic nations first developed often had the secondary, at times paradoxical result that they also weakened the functional structures of national societies and their institutional orders. From the outset, as mentioned, the constitutional vocabulary of national citizenship and popular sovereignty

\footnotetext{
${ }^{49}$ See Germani supra note 10.
} 
contained legitimational claims, expressed at the normative level, which, at the functionalstructural level, obstructed the processes of national institutional integration and nation building more widely, to which they otherwise contributed.

The first core antinomy inherent in constitutional concepts linked to citizenship results from the fact that, in its classical construction, the theory of national citizenship did not confer determinate form on the citizen that was constitutionally expected to bring legitimacy to the functions of government. In early constitutional doctrine, the citizen was projected as a simple member of the sovereign nation, defined generically as an agent authorized to shape the legal order of the nation owing to his or her (almost always his) inherent attributes of freedom, equality and territorial membership. ${ }^{50}$ In this respect, the vocabulary of national citizenship created a series of deeply unsettling problems for actual constitutional practice and for actual processes of national integration and democratic state formation.

At one level, as discussed, the concept of the citizen underscored the growth of political institutions with sovereign status, able to integrate an increasingly large proportion of national citizens. Yet, the fact that the citizen was constructed in socially indeterminate categories meant that, as national political institutions expanded their sovereign force into society, they were required to integrate and, to extract legitimacy from, citizens in a form that was ill-matched to their original constitutional definition. By the later nineteenth century, most states in Europe possessed moderately extended electoral franchises, and, in most societies, citizens had been partly incorporated in the political systems on which they conferred legitimacy. By 1918, such incorporation had frequently reached an advanced level, so that, by this juncture, many states in Europe and some in the American continent were

\footnotetext{
${ }^{50}$ P. Rosanvallon, Le Sacre du citoyen (1992).
} 
legitimated by immediate reference to their (still primarily male) citizens. In this process, however, citizens increasingly appeared to political institutions, not as equal rights-holding agents defined by simple membership in a national community, but as manifestly unequal agents, attached to potentially hostile positions within national systems of social stratification. In consequence, as they penetrated further into society to extract legitimacy from citizens, national political institutions were obliged to manufacture their legitimacy, not by simply representing the collective will of their citizens, but through actions designed to mediate between opposing constituencies and to placate the more acute social conflicts that emerged between opposed citizenship groups. ${ }^{51}$

In virtually all societies, national political institutions were ultimately unable to mediate conflicts between different factions of the national citizenry. In virtually every line of national state formation, the emergence of mass democracy created a situation in which political institutions collapsed as they reacted to expectations arising from the generalization of electoral citizenship as a legitimational norm. As broad electoral enfranchisement became the rule, most societies, either once or cyclically, entered a condition in which their political systems abandoned the attempt to reconcile rival citizenship claims, and dominant citizenship groups simply annexed the public apparatus of government to promote their own prerogatives. ${ }^{52}$ In such situations, most states experienced a period of chronic institutional privatization, usually expressed in elite colonization of government, such that the integrational force (sovereignty) of national institutions was diminished. ${ }^{53}$ Inter-group

\footnotetext{
${ }^{51}$ In most societies, the advent of mass-democracy in 1918 saw the growth, more tentatively, of welfare democracy, and most democratic polities that emerged in 1918 contained complex mechanisms for the integration of organized labour.

${ }^{52}$ Classical examples are fascist states in Europe in the 1920s and 1930s and Latin American states after 1945.

${ }^{53}$ For examples of the privatization of public resources in authoritarian states see P. Ranis, Argentine Workers. Peronism and Contemporary Class Consciousness (1992); H.M. Makler, 'The Portuguese Industrial Elite and its Corporative Relations: A Study of Compartmentalization in an Authoritarian Regime', 24(3) Economic Development and Cultural Change (1976); F. Bonini, Storia della pubblica amministrazione in Italia (2004), at 98; J. Willerton, Patronage and Politics in the USSR (1992).
} 
conflicts of this kind were naturally not caused by constitutions, and their origins were not eminently constitutional. However, the fact that national governments were committed to mediating interests of citizens conferred political form on the divisions expressed in such conflicts, and it meant that legitimacy in the discharge of basic government functions presupposed both palliation and politicization of deep societal antagonisms. In most societies, political institutions were not capable of mediating, or even of mollifying, the inter-group tensions politicized by the original legitimational norm of the citizen.

The second core antinomy inherent in the constitutional concepts attached to citizenship is determined by the fact that, in these concepts, the sovereign citizen is imagined as an actor that stands in an immediate relation to the state. As explained, the close legitimational nexus between citizen and state originally drove the penetration of government bodies into the different functional domains in society, eliminating the countervailing force of local authorities; as such, it is vital to the integrational form of national society. At the same time, however, the expectation of immediacy in the construction of the citizen led to acute crises in the functional consolidation of national societies, centred around, and integrated in, national political institutions.

In most societies evolving towards national form, the idea that the state is legitimated by an immediate relation to the citizen meant that demands for integration and representation in all parts of society converged in unsettling manner around the political system. In particular, this idea concentrated exchanges between government and society around tightly constructed lines of communication, articulated through legislative bodies. Earlier constitutional theory almost invariably expressed the assumption that legislatures are the core institutions of government, and legislation in the popular interest is the defining act of legitimate public 
authority. ${ }^{54}$ On the path towards modern democracy, however, the focusing of legitimacy on legislative acts often proved illusory and destabilizing. As states assumed growing regulatory functions, legislatures usually lost efficacy in the production of legislation, and growing demands for regulation resulted in the proliferation of administrative units within the state, which absorbed many legislative responsibilities. In many early democracies, further, newly created administrative organs tended to coalesce with powerful structured organizations, tied to elite societal interests, which were then able to intervene in legislative procedures, often placing unsettling pressure on political institutions. These processes were frequent in democracies created after $1918 .{ }^{55}$ Moreover, the legitimational focus on legislatures meant that hostile social groups often attached their deep-lying social rivalries to contests over particular acts of legislation, so that single law-making institutions become foci for very densely articulated inter-factional conflicts. In many cases, this had the result that legislative institutions were unable to pacify social antagonisms, and they lost the power to generate consensual premises for legislation. In many cases, further, this meant that legislative institutions were susceptible to colonization by the more powerful actors in the balance of social conflict, and they collapsed in face of hostilities between the groups of citizens to which they owed their legitimacy. These occurrences were also frequent in early massdemocratic polities in the 1920 s. $^{56}$ Overall, national political systems that projected their legitimacy through the immediate transposition of the interests of national citizens into legislative outcomes rarely survived long, and, in most settings, the constitutional order of the

\footnotetext{
${ }^{54}$ In Britain, this was expressed in the doctrine of parliamentary sovereignty. See W. Blackstone, Commentaries on the Laws of England, vol. I. (1979 [1765-1769]). In the French Revolution, Saint-Just stated that the 'legislative body is ... the essence of liberty': L.A.L.de Saint-Just, Esprit de la Révolution et de la Constitution de France (1791), at 102. 55 See as examples of these processes M. Geyer, 'Ein Vorbote des Wohlfahrtsstaates. Die Kriegsopferversorgung in Frankreich, Deutschland und Großbritannien nach dem Ersten Weltkrieg', 9(2) Geschichte und Gesellschaft (1983); N. Roussellier, La force de gouverner. Le pouvoir exécutif en France. XIX-XXI siècles (2015), at 544; C. Böhret, Aktionen gegen die kalte Sozialisierung 1926-1930. Ein Beitrag zum Wirken ökonomischer Einflußverbände in der Weimarer Republik (1966); M. Grübler, Die Spitzenverbände der Wirtschaft und das erste Kabinett Brüning: Vom Ende der Großen Koalition 1929/30 bis zum Vorabend der Bankenkerise 1931 (1982).

${ }^{56}$ Fascist intellectuals commonly reflected on the illusion of legislative authority, and the vulnerability of legislatures to sabotage. See C. Schmitt, Die geistesgeschichtliche Lage des heutigen Parlamentarismus (1923).
} 
state fractured in face of hostile groups in society demanding influence in the legislative process.

A third antinomy in the constitutional concepts connected to citizenship lies in the fact that modern citizenship has its origins in fundamental social conflicts, and it tends, necessarily, to intensify the force of social antagonisms around the state. In fact, the modern concept of the citizen is profoundly connected to military combat, and it expresses a legitimational principle that, historically, imprinted an intensely conflictual form on national societies and their political institutions.

The connection between citizenship and military combat is manifest in the fact that most national societies established integrated citizenship through war, and, in most national polities, citizens first appeared as subjects of legitimation in contexts determined by war. At the structural level, most societies originally acquired national form as citizens experienced inner homogenization and trans-sectoral assimilation through military activities. This occurred most obviously in societies undergoing civil war or wars of unification, in which war forcibly removed some societal and territorial divisions in nascent nations. ${ }^{57}$ In most societies, however, it was through shared participation in military mobilization that citizens from different regions and different sectors in the same society first entered immediate nationally formative - proximity to one another. ${ }^{58}$ Moreover, in most societies, underincluded social groups typically obtained enhanced social and electoral inclusion, as full

\footnotetext{
${ }^{57}$ Speaking of Germany and the USA in the nineteenth century, one observer remarks that 'it was in the practice of war ... that both nations forged the key elements of their status in the world': M. Geyer and C. Bright, 'Global Violence and Nationalizing Wars in Eurasia and America: The Geopolitics of War in the Mid-Nineteenth Century', 38(4) Comparative Studies in Society and History (1996) 648.

${ }^{58}$ See for example A. Fletcher, Life, Death and Growing Up on the Western Front (2013), at 20; J.J. Modell, M. Goulden and S. Magnusson, 'World War II in the Lives of Black Americans: Some Findings and an Interpretation', 76(3) Journal of American History (1989) 838.
} 
citizens, through military engagement. ${ }^{59}$ This usually occurred for one two reasons.

Sometimes this occurred because, in periods of warfare, governments required additional recruits, and they were prepared to offer expanded citizenship rights so that marginal groups would enter combat. ${ }^{60}$ Sometimes this occurred because governments wished to reward citizens for military sacrifices, often to avert domestic instability caused by lack of such reward. ${ }^{61}$ Obvious examples of this can be seen in widening enfranchisement in Europe after 1918, and in the abolition of ethnically biased electoral laws outside Europe after 1945.

Overall, most modern societies were consolidated as nations, primarily, through war or preparation for war. Societies with weak military capacity or limited experience in war were usually only weakly nationalized, and citizenship did not produce a hard integrated structure for society. ${ }^{62}$

In addition, the connection between citizenship and military combat is evident in the fact that the normative core of the modern national citizen first evolved, in revolutionary France and revolutionary America, through processes of profound societal militarization, in which persons acquired citizenship and exercised rights linked to citizenship as part of a process of military mobilization. ${ }^{63}$ In both these settings, citizenship practices and military engagement were not easily separable, and membership in the Republics that resulted from citizenship revolutions had an overtly military character, depending in part on the willingness of citizens

\footnotetext{
${ }^{59}$ Classically, of course, most national societies experienced formative periods in which warfare led to the abolition of serfdom or slavery, as persons traditionally excluded from the exercise of citizenship rights were needed for conduct of military conflict, and citizenship rights were extended to such persons as part of a military bargain. More recently, a variant on this bargain observable in the USA. Of the USA, Slotkin argues that the attainment of full citizenship rights by African Americans in 1964/65 marked the fulfilment of the 'social bargain' first established through black military participation in World War I. See R. Slotkin, Lost Batallions. The Great War and the Crisis of American Nationality (2005), at 559. See also C.S. Parker, Fighting for Democracy. Black Veterans and the Struggle against White Supremacy in the Post-War South (2009), at 12.

${ }^{60}$ See J.W. Chambers II, To Raise an Army. The Draft Comes to Modern America (1987). But it has also been widely argued that working-class enfranchisement in the UK after 1914 was connected to manpower requirements. See R. Roberts, The Classic Slum. Salford Life in the First Quarter of the Century (1971).

${ }^{61}$ M. Pugh, Electoral Reform in War and Peace 1906-18 (1978), at 51.

62 See M.A. Centeno, Blood and Debt. War and the Nation-State in Latin America (2002), at 170.

${ }^{63}$ One historian describes military conscription in France as 'apprentisage de la citoyenneté': A. Crépin, La conscription en débat ou le triple apprentissage de la nation, de la citoyenneté, de la république (1798-1889) (1999), at 13.
} 
to perform military service. ${ }^{64}$ In both settings, constitutionalism evolved as a doctrine that placed the active citizen at the centre of government, so that, for the first time, norms created through active participation of citizens formed the constitutional bedrock of government. In both settings, however, the citizens acquired rights of active participation in return for willingness to act as soldiers, so that the experience of becoming a citizen was not easily separable from the experience of becoming a solider. After the revolutionary period, then, the expansion of electoral rights was frequently tied to military conscription. ${ }^{65}$ In most nineteenth-century nations, the deepening of democracy through increasing enfranchisement and the inner militarization of society through deepening conscription usually went hand in hand. ${ }^{66}$

The linkage of citizenship and military conflict typically had far-reaching implications for the formation of national society, depending on the nature of the conflict that forged national citizenship bonds. Generally, the results of this linkage challenged the processes of social integration that underpin the formation of national democratic societies, so that the basic construction of the citizen blocked the factual trajectory of democratic nation building required for the exercise of citizenship rights. Where citizenship was formed, or extended, through war with external adversaries, it was often envisaged as a very tight affective bond, connecting members of society directly to each other and directly to the political institutions that were conducting war. In many such cases, this intensified the presumption of immediacy in the relation between citizens and government, so that the legitimacy of government was tied to the expectation that citizens would be comprehensively incorporated in the political

${ }^{64}$ J.-P. Bertaud, La revolution armée. Les soldats-citoyens et la Révolution en France (1979); L. D. Cress, Citizens in Arms. The Army and the Militia in American Society to the War of 1812 (1982); W. Gembruch, Staat und Heer. Ausgewäblte historische Studien zum ancien régime, zur Französischen Revolution und zu den Befreiungskriegen, ed. J. Kunisch (1990); T. Hippler, Soldats et citoyens. Naissance du service militaire en France et en Prusse (2006).

${ }^{65}$ See Crépin supra note 63, at 92, 125; S. Tarrow, War, States, and Contention. A Comparative Historical Study (2015), at 241.

${ }^{66} \mathrm{~J}$. Leonhard, Bellirismus und Nation. Kriegsdeutung und Nationsbestimmung in Europa und den Vereinigten Staaten 1750-1914 (2014). 
system. An important example of this can be found in World War I, after which the mass enfranchisement of male populations in Europe was widely accompanied by the conviction that the state should act as a primary guarantor of material wellbeing for all citizens. Where such expectations were subsequently disappointed, however, the terms of national citizenship often became matters of violent contest, prolonging military attitudes into peacetime. ${ }^{67}$ Where citizenship was formed through civil war, similarly, the lines of conflict that shaped the war usually persisted beyond the end of combat. In some societies emerging from civil war, holders of executive authority simply used their power to protract, at a diminished level of intensity, the conflict in which they originally acquired their positions. ${ }^{68}$ In other such societies, contests over citizenship remained enduringly affected by the oppositional interests first expressed in civil war, so that low-level civil war became part of everyday political life. ${ }^{69}$ Most states based in ideals of citizenship originated in situations marked by some aspects of civil war, and after their emergence they retained a deeply militarized character. In the longer wake of 1789 , for example, in most European societies rival political groups explained their prerogatives in emphatically military terms. In many states, further, early political parties developed in military settings, and they were backed by groupings with military capacity. ${ }^{70}$ In interwar Europe, tellingly, most polities developed systems of electoral competition in which political parties were not categorically distinguishable from military

\footnotetext{
${ }^{67}$ In many European countries, mass enfranchisement after 1918 was accompanied by the formation of paramilitary attachments, linked to different political parties. See R. Gewarth, The Vanquished. Why The First World War Failed to End, 1917-1923 (2016). Even in the UK, the creation of the (nearly) full male franchise in 1918 created a climate in which politicians conducted political activities in subdued fashion, to avoid intensified volatility. See J. Lawrence, 'The Transformation of British Politics after the First World War', 190 Past \& Present (2006) 213.

${ }^{68}$ Key examples are post-1791 France and post-1921 Russia.

${ }^{69}$ Examples are persistent inter-ethnic conflicts in the USA after 1865 and persistent class conflicts in Germany after 1918.

${ }^{70}$ In France, parties began to develop in 1789, and party government was stabilized in 1870-75, after the mass murder of the political left. In Germany, political parties appeared in 1848, and dominant Conservative parties were closely linked to the army. See E. Trox, Militärischer Konservatismus. Kriegervereine und „Militärpartei” in Preußen zwischen 1815 und 1848/49 (1990). In the USA, the Republican Party was in effect the government of the Union, which defeated the Confederacy in the 1860s. See R.F. Bensel, Yankee Leviathan. The Origins of Central State Authority in America, 1859-1877 (1990), at 3-4.
} 
units. ${ }^{71}$ It is widely noted that in Latin America and Africa processes of national formation usually promoted by political parties were often strategically conducted by military organizations. $^{72}$

Throughout modern history, in consequence, states legitimated by ideals of popular citizenship have usually, as discussed, assumed a democratic emphasis. However, the original form of polities founded in citizenship is military democracy. Globally, the military dimension in the modern idea of the citizen instilled a deep volatility in national political systems. On the path to democracy, most states have undergone protracted crises caused by the fact that their primary source of constitutional legitimacy - the national citizen originated in military conditions. In most cases, further, conflict over the terms of citizenship resulted in the usurpation of political institutions by powerful elites, possessing greatest military potential, and in the resultant promotion of highly exclusionary citizenship practices, which then curtailed the integrational force of the political system in society. ${ }^{73}$ The form of citizenship in which popular sovereignty became real, in other words, was not, initially, experienced as a constitutional order marked by sovereign self-legislation or collective integration. On the contrary, it was experienced as a condition of intense societal militarization and deep institutional fragmentation.

In summary, the constructs of constitutionalism initially gave impetus to two separate sociological processes in modern society. These constructs promoted the formation of

\footnotetext{
${ }^{71}$ See Gewarth supra note 67.

72 I. L. Horowitz and E. K. Trimberger, 'State Power and Military Nationalism in Latin America', 8(2) Comparative Politics (1976) 233; F.D. McCann, Soldiers of the Pátria. A History of the Brazilian Army, 1889-1937 (2004), at 437; V.P. Borges, Tenentismo e revolução brasileira (1992), at 158.

${ }^{73}$ On loss of institutional integrity under military-led regimes see C. Bersani, 'Gli enti pubblici tra stato e società 1926-1943', in A. Mazzacone (ed), Diritto, economia e istituzioni nell'Italia fascista (2002); D. Rebentisch, Fübrerstaat und Verwaltung im Zweiten Weltkrieg. Verfassungsentwicklung und Verwaltungspolitik 1939-1945 (1989), at 2; S. Borner and M. Kobler, 'Strength and Commitment of the State: It Takes Two to Tango: A Case Study of Economic Reforms of Argentina in the 1990s', 110(3/4) Public Choice (2002) 340.
} 
society, simultaneously, on a democratic design and a national design: they described political subjects engaged in law-making actions, and they created conditions of national integration in which these democratic subjects could appear and exercise sovereignty. In most cases, however, these processes initiated by constitutionalism did not approach completion, at least as long as constitutional concepts were articulated in classical national form. Most societies were eventually defined by the failure of both processes - by failed democratization and by failed nationalization. Most national societies that embarked on a path toward democratization arrived, ultimately, at a condition that fell short of government by sovereign peoples. Some such societies arrived at a state of intermittent democracy, in which shortlived periods of full political integration stimulated a brutal backlash amongst elites, who then used democratic instruments to assume control of the means of social coercion. ${ }^{74}$ Some such societies arrived at a condition of partial democracy, in which full democratic inclusion remained a privilege for designated social groups, so that some groups were excluded on grounds of socio-economic class position, ethnicity or gender. In both categories, the constitutional norm of popular sovereignty was not materially elaborated. ${ }^{75}$ Although originally imagined as a system of collective liberation, constitutional democracy actually evolved as a system of selective repression, in which public institutions were monopolized to secure elite positions in society. Likewise, national societies that embarked on processes of structural integration did not acquire fully national form, and national political institutions lacked the effective sovereignty to integrate all social groups. In the more compactly nationalized states of Europe, social and territorial integration remained patchy until after 1945. In the USA, the process of societal nationalization was not completed until the mid-

\footnotetext{
74 This category includes European states between 1918 and 1940, most of which momentarily became (partial) democracies and then became authoritarian. It also includes many post-colonial states in Africa. Most Latin American states fit this model until the 1980/90s.

75 This includes most states at some point in their trajectory, as generalized political inclusion only became widespread after 1945. As recent paradigms, it includes South Africa until 1991-96 (ethnic exclusion); the USA until 1964/65 (ethnic exclusion); the UK until 1950 (class-determined over-inclusion). Elements of this model are found in Bolivia until 2009 (ethnic exclusion); Colombia until 1991 (ethnic exclusion); Switzerland until the 1970s (gender exclusion).
} 
1960s, when a system of legal norms was created that was (at least notionally) centrally enforceable across all territorial regions in the country. In less integrated societies, for example in Latin America, national integration remained very fitful until later in the twentieth century. ${ }^{76}$ In most African countries, national integration only began during decolonization, and it remains today demonstrably weak. ${ }^{77}$

On balance, very few national societies whose normative self-comprehension was founded in constitutional democracy evolved sovereign political institutions, capable of integrating national citizens in generally inclusive (democratic) fashion, and very few national societies acquired conclusive national form. In most societies, norms of citizenship that promoted democratization were unable to solidify structures of national integration, in which democratic practices could be stabilized. The primary subjects of constitutionalism remained, in essence, unreal.

Global norms and national formation

Striking in this regard is the fact that democratic political systems and fully national societies were not common until after 1945, and they were not generally developed until the 1980s. Increasing democratization and national integration eventually coincided with the early formation of the global system of legal norms, strongly connected to the promotion of human rights law after 1945, promoted by the UN and other international organizations with regional focus and authority. At this point, both in their own societies and in their external relations, national states became subject, however notionally, to a higher set of laws, originating and located outside national legal systems, which were strong enough to shape both constitutional

\footnotetext{
${ }^{76}$ See for a summary of research on this G. O’Donnell, 'Y a mí qué me importa? Notas sobre sociabilidad y política en Argentina y Brasil', Kellogg Institute, Working Paper \# 9 (1984), at 21

${ }_{77}$ Many African societies are marked by a multi-centric or even multi-sovereign legal-political landscape. See R.E. Howard, 'Legitimacy and Class Rule in Commonwealth Africa: Constitutionalism and the Rule of Law', 7(2) Third World Quarterly (1985) 331.
} 
and statutory decisions of governments within their own territories. As a result, the formation of national democracies and national societies more broadly began to become widespread at a point in time when the formal sovereignty of national states was increasingly restricted. In fact, processes of democratization and integration within national societies were historically shaped by, and ultimately contingent upon, the emergence of a globally overarching normative order. As widely noted, the integrational impact of global norms in national societies did not result from the simple forcible imposition of such norms. ${ }^{78}$ Manifestly, the system of global norms was not originally backed by strong coercive institutions, and the global rise of human rights law did not form a hard causal substructure for the expansion of democracy. Nonetheless, norms established in the global domain filtered into national society through a range of practices, often very contingent in nature, slowly elaborating shared normative structures to coordinate social integration and to underscore citizenship practices. Few societies became democracies without domestic exposure to international human rights law. Discernibly, such norms proved conducive to democratic formation and nation building as they impacted on patterns of conflict within domestic societies, and they softened the antinomies inherent in purely national patterns of constitutional legitimation, integration and subject construction. In so doing, they allowed national populations to assume a secure role as sovereign political actors, within sovereign national institutions.

This can be observed in a number of different ways.

First, international human rights law intensified the integrational force of political institutions in national societies, and it led to increased convergence of society around sovereign political organs.

\footnotetext{
${ }^{78}$ See B. Simmons, Mobilizing for Human Rights. International Law in Domestic Politics (2009).
} 
As discussed, in most classical national societies, the ability of political institutions to extend sovereign power deeply into society was limited. To be sure, the political systems of some societies acquired heightened integrational force in the nineteenth century, and then again, more intensely, in and after World War I. Later, many national societies witnessed experiments, usually in the middle third of the twentieth century, in which centralized institutional construction was promoted in accelerated fashion, to force societies into convergence around organs of national governments. Long into the twentieth century, however, national societies typically retained, or recurrently reverted to, a patchwork design, in which local actors and authorities acted at a high degree of autonomy, often outside the jurisdiction of formal institutions. ${ }^{79}$ In most settings, the formation of state institutions able to imprint a cohesive and integrated form on society was only realized as these institutions extracted legitimacy from normative principles formed outside national societies, especially from global human rights law.

The role of global human rights law in promoting institutional sovereignty and national integration became visible in diverse fashion in different settings, and only a few variations on this process can be described here. As one example, many states with federal constitutional systems acquired heightened integrational force after 1945. In this process, typically, states obtained the power to unify different sub-national regions in society as they internalized human rights norms in their constitutional order. This usually meant that state agencies obtained authority to cut through normative distinctions between different regions, and to impose a single sovereign order on society as a whole. ${ }^{80}$ In extreme cases,

\footnotetext{
${ }^{79}$ See discussion supra notes 76-77.

80 B. Pirker, Grundrechtsschutz. im Unionsrecht zwischen Subsidiarität und Integration (2018) at 95. The USA is a case in point, as the federal imposition of civil rights law across all parts of the country in the 1960s was strongly backed by
} 
presumptions in favour of human rights law led to the de facto military occupation of regions that refused to show compliance with the core legal norms of society as a whole. ${ }^{81}$ Alongside this, many states in societies with a long history of informal resistance to powers exercised by national government bodies assumed higher integrational force after 1945, so that local organizations lost the ability to extricate themselves from the legal order defined at national level. In this process, the penetration of global human rights into domestic law played an important role in removing counterweights to the integrational force of government bodies, and in instilling a single normative grammar in society.

For example, in Japan, the authority of the central state had historically been weakened by clusters of informal authority attached to household regimes. After 1945, globally defined legal rights assumed new prominence in Japanese society, and one outcome of this was that localized sources of power forfeited importance. ${ }^{82}$ This does not mean that the constitutional order of post-1945 Japan simply gave comprehensive effect to international human rights law, removing all traces of pre-modern power structures. It is commonly observed that after 1945 individual rights were less strongly protected in Japan than in other post-authoritarian states. ${ }^{83}$ However, the post-1945 constitutional order promoted an individualization of legal status claims, reflecting global human rights law, and this helped to dissolve historical accretions of local, familial and economic power that curtailed the societal purchase of government. ${ }^{84}$ In the USA, analogously, growing endorsement of international human rights

\footnotetext{
international presumptions. See J.D. Skrentny, The Minority Rights Revolution (2002); A.S. Layton, International Politics and Civil Rights Policies in the United States, 1941-1960 (2000).

81 See Eisenhower's use of military power to impose national citizenship laws at Little Rock in 1957, insisting that 'the force we send there is strong enough that it will not be challenged': see M. Sherry, In the Shadow of War. The United States since the 1930s (1995), at 25. The US army was of course the vanguard institution in the consolidation of civil rights.

82 R.P. Dore, Land Reform in Japan (1959), at 25.

${ }^{83}$ L.W. Beer, 'Group Rights and Individual Rights in Japan', 21(4) Asian Survey (1981): 442, 453.

84 The Japanese language did not have words for 'rights' until the 1860s. See C. Tsuzuki, (2000), The Pursuit of Power in Modern Japan (2000), at 77. Constitutional reform in Japan was flanked by extensive land reform (1947-49),
} 
law progressively restricted the force of local norms and informal modes of authority. It is commonplace to observe the USA as a polity that exemplifies resistance to international human rights law. ${ }^{85}$ However, the USA is in many ways a paradigmatic case for polities whose integrational structures are crafted through interaction between national actors and international norm setters. The USA was formed, finally, both as an integrated nation state and as an integrated democracy in the period 1945-1964/65, as the capacity of local elites in the southern states to extricate themselves from federal laws was reduced, and rights of democratic citizenship were evenly extended to all social groups. ${ }^{86}$ This overlapping process of state formation and democratization cannot easily be explained without consideration of the force of global legal norms. This process was propelled, in part, by anxiety in the executive branch about the standing of the USA in the global inter-ideological conflict with the Soviet Union, and it was driven both by presidential imposition of international human rights principles and by executive support for legal actions likely to harden the purchase of such norms in the national legal system. ${ }^{87}$ In the 1940s and 1950s, the Ministry of Justice provided amicus curiae briefs, often based in international law, to support plaintiffs in leading desegregation cases. ${ }^{88}$ This process was also conducted by judicial institutions, which, even although rarely according international norms decisive force in cases relevant for the quality of democracy, found ways to align domestic constitutional principles to global expectations. ${ }^{89}$ In cases of extreme prevalence of informal power structures, exemplified in Africa and Latin

implemented by the American occupying government, which abolished sharecropping and was to eradicate feudal traces from society.

${ }^{85}$ See strident declarations to this effect in J.A. Rabkin, Law without Nations? Why Constitutional Government requires Sovereign States (2007).

${ }^{86}$ See R. Mickey, Paths out of Dixie. The Democratization of Authoritarian Enclaves in America's Deep South, 1944-1972 (2015).

${ }^{87}$ See Skrentny supra note 80.

88 See S.H. Cleveland, 'Our International Constitution', 31 Yale Journal of International Law (2006); J.T. Elliff, The United States Department of Justice and Individual Rights 1937-1962 (1987), at 254.

${ }^{89}$ See the declaration of the commitment of the American Supreme Court to the 'achievement of fair and effective representation for all citizens' in Reynolds v. Sims, 377 U.S. 533 (1964). This case was not centrally concerned with anti-minority politics. However, it made clear the Court's insistence on its political role in promoting equal access to the electoral franchise, and it strongly attached domestic constitutional law to norms set out in the global arena in the mid-1960s, especially to the International Covenant on Civil and Political Rights, which was first presented in draft form as early as 1954 . 
America, the linkage of national law to global human rights law became a mainstay in intensified processes of nation building that occurred in the later twentieth century and beyond. Perhaps the most emblematic example of this is Colombia, a state historically defined by the fact that, owing to the long-standing civil conflict, central institutions did not pierce far into society, and non-governmental bodies, often with military capacity, created informal micro-states within national territory. ${ }^{90}$ The eventual incorporation of Colombian society into one integrated legal/political system was strongly shaped by the imposition of globally defined norms on society. Such norms possessed integrational force because, as they originated outside national societies, they could claim some authority amongst all parties in the civil conflict, which meant that the vocabulary of human rights law emerged as a unique shared social diction. ${ }^{91}$ In many instances, national institution building in Colombia was ordained by law courts, citing direct authority under international human rights treaties. ${ }^{92}$

In these processes, the basic institutional preconditions of national democracy and national society - i.e. institutions able to exercise a monopoly of power and to integrate national citizens - only developed on the foundation of norms derived from the global legal system. The sovereignty of national institutions and nationhood more widely were constructed through a process in which national constitutional law was integrated in global constitutional law. In fact, the essential subjects of constitutional democracy - sovereign citizens, in sovereign states, in national societies - only took shape on a global legal substructure.

\footnotetext{
${ }^{90}$ M. Aguilera Peña, Contrapoder y justicia guerrillera, fragmentación politica y orden insurgente en Colombia (1952-2003) (2004); A. Arjona, Rebelocracy. Social Order in the Colombian Civil War (2016), at 81.

${ }^{91}$ See historical reconstruction in J. Grajales, Gobernar en medio de la violencia. Estado y paramilitarismo en Colombia (2017), at 59-61; Jorge González Jácome, Estados de Excepción y democracia liberal en América del Sur: Argentina, Chile y Colombia (1930-1990) (2015), at 231-32.

92 See C. Thornhill, The Sociology of Law and the Global Transformation of Democracy (2018), at pp. 350-374.
} 
Additionally, second, international human rights law created the framework for more effective articulation between national political institutions and national citizens.

The corpus of human rights law that came into being after 1945 was underpinned by the assumption that citizens of national polities possess rights as singular subjects: that is, in the first instance, that citizens exercise rights as rights that attach, singularly, to their bare subjectivity, prior to their incorporation into any shared associational order. This had particular importance in the process of democratic consolidation that occurred after World War II. At this time, it was widely perceived that democratic polities created after 1918 had been vulnerable to political sabotage because they had sanctioned corporatistic constructions of rights, allowing collective economic organizations to acquire powerful positions in the peripheries of government. ${ }^{93}$ This also had importance because the allocation of singular rights was perceived as an alternative to the public-legal systems of interwar Fascist regimes and post-1945 Communist polities, in which structured associations, such as trade unions, professions, corporations and military bodies, were accorded constitutional protection. ${ }^{94}$ The patterning of constitutional rights on an individualistic design was deeply shaped by the power of norms emerging at the international level, ${ }^{95}$ which clearly attributed rights to persons in particular, abstract form.

This global-individualistic reorientation of human rights law entailed a revision of the classical construction of legitimacy for governmental functions. As global human rights law

\footnotetext{
93 The development of human rights law in post-fascist states was closely linked to processes of economic decartelization. See chapters in B. Diestelkamp, Z. Kitagawa, J. Kreiner, J. Murakami, K. W. Nörr and N. Toshitani (eds), Zwischen Kontinuität und Fremdbestimmung. Zum Einfluß der Besatzungsmächte auf die deutsche und japanische Rechtsordnung 1945 bis 1950 (1996).

${ }^{94}$ See supra note 55. On the Cold-War background to human rights law in Europe see M.R. Madsen, La genèse de l'Europe des droits de l'homme. Enjeux juridiques et strategies d'état (France, Grande-Bretagne et pays scandinaves) (2010).

${ }^{95}$ For example, the catalogue of rights in the West German Grundgesetz which later became a model for constitutions in Eastern Europe, was based on drafts for the UN Universal Declaration. The Bills of Rights in Anglophone Africa were largely based on the ECHR. On international influences in civil-rights law in the USA see Skrenty supra note 80 .
} 
entered national societies, the legitimacy of national political systems was directed away from the principle that a government acquires authority if it translates the interests of citizens into legislative form, mediating such interests into laws recognized by citizens as reflecting a shared sovereign will. Instead, the principle was established that government displays legitimacy by recognizing in law an invariable singularized construction of the citizen, reflected as a subject in possession of certain basic rights. As governmental legitimacy was linked to globally projected rights, thus, national polities were able to demonstrate legitimacy in categories separate from the factual citizens to whom legislative power was applied, so that the recursive cycle of legitimacy inherent in classical democratic systems, based in the maintenance of a constant line of communication between state and citizens, was partly suspended. In some ways, the reorientation of legitimacy under the emergent system of global human rights law meant that factual citizens were removed from their original constitutional position as sovereign authors of legislation. The rise of individual rights meant that legitimacy could be constructed for law through reference to a system of norms detached from concrete existing citizens, and laws could be partly authorized and legitimated without reference to citizens in their manifest form.

At an institutional level, this reorientation of political legitimacy had three primary results, each of which tended to consolidate national democracy and national institutions, and to heighten the integrational form of national society more widely.

First, after 1945, democratic systems were increasingly established in which legislative organs were less exposed to inter-fractional pressures and less likely to internalize collective associations of citizens as sources of legislation and legitimacy. The fact that governments established their legitimacy by proportioning laws to citizens as singular rights holders meant 
that the original legitimacy of law was attached to a formal abstract source, outside the immediate governmental order. As a result, it became more difficult for collective associations to monopolize the production of law and legitimacy, and access to legislative power was more securely protected. To be sure, this was not universally the case. Some post1945 societies continued to experiment with patterns of democracy in which citizens were fully incorporated in government. ${ }^{96}$ After 1945 , moreover, structured organizations very manifestly did not lose power in new democracies, and patterns of cross-class compromise central to the public economies and welfare systems of post-1945 states were usually established through the balancing of interests represented by different organizations. At this time, nonetheless, interactions between organizations and actors in political institutions tended to take place in less unsettling fashion. In particular, organizations usually assumed more differentiated and specified roles, focused on promoting distinct sectoral objectives. It became less frequent, for example, for powerful economic organizations to mobilize entire social groups or classes, or to interlock fully with religious associations or political parties, and they emerged instead as partners in multi-focal social agreements. ${ }^{97}$ This meant that the ability of organizations to displace elected governments or colonize state resources was diminished, ${ }^{98}$ and the legislative organs of government acquired greater control of political

\footnotetext{
${ }^{96}$ Examples are Argentina under Peron, Bolivia in 1952, and Venezuela in 1958. For comment see R.B. Collier and D. Collier, Shaping the Political Arena. Critical Junctures, The Labor Movement, and Regime Dynamics in Latin America (1991), at 342; M. Burke and J. M. Molloy, 'From National Populism to National Corporatism: The Case of Bolivia (19521970)', 9 Comparative International Development (1974).

${ }^{97}$ See for example B. Ebbinghaus, 'The Siamese Twins: Citizenship Rights, Cleavage Formation, and Party-Union Relations in Western Europe', 40(3) International Review of Social History (1995); H. Volkmann, 'Modernisiering des Arbeitskampfes? Zum Formwandel von Streik und Aussperrung in Deutschland 1864-1975' in H. Kaelble (ed), Probleme der Modernisierung in Deutschland. Sozialhistorische Studien zum 19. und 20. Jahrbundert (1978), at 168; W. Korpi, The Democratic Class Struggle (1983), at 21; G. Ross, Workers and Communists in France. From Popular Front to Eurocommunism (1982), at 314; H.G. Hockerts, Hans Günter (1988), 'Integration der Gesellschaft - Gründungskrise und Sozialpolitik in der frühen Bundsrepublik' in M. Funke (ed), Entscheidung für den Westen. Vom Besatzungsstatut zur Souveränität der Bundesrepublik 1949-1955 (1988), at 55.

${ }^{98}$ In different waves of democratic transition - after 1945, in the mid-1970s, after 1983 - constitutions limited the role of the army in government. Such constitutions also restricted the extent to which trade unions and large businesses could assume dominant positions in government.
} 
bargaining processes, in a form solidified against other bodies. ${ }^{99}$ The recognition of citizens as holders of rights outside the grammar of social conflict, in other words, had the result that legislation tended to reflect more generalized constructions of citizenship, and governmental actors acquired the ability to pass laws at a heightened degree of autonomy and sovereignty.

Second, after 1945, the fact that citizens acquired individual rights, increasingly predefined in a global normative order, meant that privileged constituencies in national society found it harder to utilize political institutions as instruments to exclude persons with minority affiliations from the system of political competition. After 1945, the number of democracies that excluded particular social memberships - for instance, on grounds of ethnicity, gender, or socio-economic position - declined rapidly, and the selective privileging of electoral groups proved increasingly hard to legitimate. ${ }^{100}$ This was again due, in part, to the fact that the legitimacy of national governments was constructed through the replication in domestic laws of normative expectations defined outside national society. As a result, the exercise of variable rights, not centrally defined by the political system, became less frequent, ${ }^{101}$ and different groups in society entered a more even relation to the national political system. Through this, national populations were progressively integrated within a single normative order, and political institutions imposed increasingly uniform (sovereign) authority across society as a whole.

\footnotetext{
${ }^{99}$ In some cases, notably Argentina after 1983, rights-based constitutionalism was strategically designed to separate the core state structure from powerful societal organizations. See G.L Munck, Authoritarianism and Democratization. Soldiers and Workers in Argentina, 1976-1983 (1988), at 155.

100 One account argues that widespread enfranchisement of women after 1945 was due to the socializing power of international norms: F.O. Ramirez, Y. Soysal and S. Shanahan, 'The Changing Logic of Political Citizenship: CrossNational Acquisition of Women's Suffrage Rights, 1890 to 1990,' 62(5) American Sociological Review (1997). On my view, this can be extended to wider processes. Before 1945, few societies had comprehensive enfranchisement. 101 Most cases in which unjustly favoured sectors have lost group privileges have been shaped by domestic reception of international law. Obvious examples are the USA around 1964 and South Africa in the early 1990s.
} 
What this amounts to, third, is that after 1945 a solid stratum of rights entered national societies, which softened - or partly demilitarized - the lateral conflicts between national citizens. Through the rise of global human rights law, conflict between rival citizenship groups lost its central importance as the basic source of law, and laws could be authorized by reference to rights that were stabilized prior to, or separate from, concrete social antagonisms. In this respect, globally defined legal rights led to the deep pacification of the procedures in which citizens assumed sovereign power. The global environment after 1945 retained the same propensities for conflictual patterns of citizenship that marked the interwar period. In fact, all post-1945 polities were in some way defined by their position in the ideological conflict between the USA and the USSR, and core states in this conflict became, at an institutional level, more militarized than had previously been the case. ${ }^{102}$ However, amidst this global militarization, national societies increasingly developed models of internal citizenship integration that were slightly disarticulated from external conflicts, and the global promotion of human rights limited the domestic penetration of global conflicts as a source of citizenship. One indicative characteristic of post-war European politics, for example, is that political parties of the far left developed individualized political programmes, strongly linked to international human rights agreements. As a result, they increasingly refused to link their stance to the ideological orthodoxy of the Soviet Union, and they campaigned on platforms outside global ideological dichotomies, which were less likely to structure inner-societal conflicts around global polarities. ${ }^{103}$ The construction of the citizen as global rights holder meant that the citizen could bring legitimacy to laws without conflict with other citizens, and the state could obtain legitimacy on a foundation that was not solely defined by its ability to mediate concrete antagonisms or consolidate positions arising from social conflict, likely to be inflamed by

\footnotetext{
102 On the USA see Sherry supra note 81, at 259; R.U. Thorpe, The American Warfare State. The Domestic Politics of Military Spending (2014), at 15. On the UK see D. Edgerton, Warfare State: Britain 1920-1970 (2005).

103 See A. Brogi, Confronting America. The Cold War between the United States and the Communists in France and Italy (2011), at 365 .
} 
international ideological positions. International human rights law obtained its most farreaching result in the fact that it helped to pacify the basic subjective unit of national society - the sovereign citizen - so that the citizen could assume its designated functions as a source of legitimate law and a central reference in processes of social integration and centralized institution building.

In these respects, on one hand, popular sovereignty only eventually became real as it was exercised on global normative foundations. The basic subjects of constitutional law, originally articulated as a source of legitimacy in the eighteenth century, only approached reality as the citizen appeared in the national political system in a form predetermined by, or mediated through, global human rights law. This body of human rights law detached the citizens represented in processes of legislation from actual material citizens, allowing citizens to enter the political system as participants in legislative practices in controlled, highly constitutionalized fashion. In turn, this helped to confer secure form on the production of legitimacy within the national political system, so that political institutions were able reliably to legislate, in sovereign form, for their citizens. The global preconstruction of the citizen made it possible for the citizen to act as the sovereign political subject of sovereign political institutions in a genuinely national society. The global preconstruction of the citizen in fact brought the normative content of citizenship into alignment with its functional-integrational preconditions. In these respects, on the other hand, national societies themselves only became real on global legal foundations. Most national societies acquired national integrational form because their institutions utilized global norms to insulate the basic source of nationhood, the sovereign citizen, against its own antinomies. The normative core of national society, the sovereign citizen, only conferred functional-integrational form on national society as it was patterned on global norms. 
The above explanation of citizenship, sovereignty and nation formation opens a new perspective to examine the current rise of neo-nationalist government. Populism is in essence a movement that mobilizes the (national) normative subjects of constitutional democracy against the (global) integrational processes, through which these subjects actually assumed reality. Populism itself gains credence because classical constitutional diction permits members of national populations, simplistically, to project themselves in sovereign political roles that it is not possible for them, in simple form, to occupy. This is the result of a deep sociological vacuity in constitutional thinking.

In this respect, emphatically, it needs to be noted that legal norms of global origin can and often do undermine the formation of democratic constitutional systems. For example, some anti-democratic regimes are propped up by powerful monetary interests protected by international investment law. ${ }^{104}$ International investment law can clearly be used to override interests within national communities, thus weakening the basic territorial foundations of popular sovereignty. ${ }^{105}$ This is widely evident in settings in which national communities are selectively dispossessed by international corporations. Moreover, some semi-authoritarian states strategically utilize international human rights law to cement their institutional hold on national societies, for purposes that are anything but democratic. ${ }^{106}$ In such cases, rejection of international laws may form a wholly legitimate expression of democratic expectations.

\footnotetext{
104 See N. Jensen and L. Wantchekon, 'Resource Wealth and Political Regimes in Africa', 37(7) Comparative Political Studies (2004) 817; A. Franke, A. Gawrich and G. Alakbarov, 'Kazakhstan and Azerbaijan as Post-Soviet Rentier States: Resource Incomes and Autocracy as a Double 'Curse' in Post-Soviet Regimes', 61(1) Europe-Asia Studies (2009) 114.

105 M.E. Margulis, N. McKeon and S.M. Borras Jr, 'Land Grabbing and Global Governance: Critical Perspectives', 10(1) Globalizations (2013) 13.

106 An example is the use of international human rights law in Russia, where rights-based litigation is incentivized as a practice that enables state agencies to consolidate their monopoly of legal authority. See C. Thornhill and M. Smirnova, 'Litigation and Political Transformation: The Case of Russia', 47(5) Theory and Society (2018).
} 
Observed closely, however, situations in which international norms undermine democracy tell us two things. First, international norms erode democracy, typically, because their imposition is backed by strong inner-societal players, often working in conjunction with international economic actors. ${ }^{107}$ In such contexts, then, assertion of national citizenship rights is itself likely to have global-legal foundations. For instance, remedies for depredatory investment practices are more fully consolidated in international law than in most domestic constitutions, and such norms have great importance in checking collusion between national elites and global economic players. ${ }^{108}$ Similarly, inner-societal opposition to authoritarian government commonly entails some mobilization of international law. ${ }^{109}$ Where global norms disrupt democratic will formation, it is common for populist movements to use this to justify wholesale hostility to global norm formation, proposing a simple figure of the national sovereign population as an alternative to international norms. However, even - or perhaps especially - in circumstances in which global norms appear to threaten democracy, national citizenship rights are likely to presuppose global-legal support. This indicates, second, that global norms retain a constant formative significance for the stabilization of democratically integrated societies, and national citizenship roles are still reliant on global norms. International norms did not only lead to democratic integration; they remain its most powerful precondition.

\section{Neo-nationalist legitimacy: Against globalism or against nationalism?}

\footnotetext{
107 An important example is the conflict over the exporting of national resources in Bolivia in the early 2000s (the guerra del gas), which led to the drafting of the new constitution under Morales, resulting in a classic case of leftpopulist government. This was both a conflict over resource sovereignty and between national elites with a globaleconomic orientation and marginalized claimants to constituent power.

${ }^{108}$ See the following case in the IACtHR: Saramaka People v. Suriname, Preliminary Objections, Merits, Reparations, and Costs, Judgment, (Nov. 28, 2017). There are numerous cases in which international principles that curb formal investment law have been reproduced in domestic courts, so that the filtration of international norms forms a core part of national sovereignty.

109 See discussion of Russia in Thornhill and Smirnova, supra note 105. See also K. Sikkink, The Justice Cascade. How Human Rights Prosecutions are Changing World Politics (2011).
} 
The above analysis does not only help to illuminate the foundations of populism. It also provides a wide sociological perspective in which we can explain the typical institutional form of populist government. We can observe that, in promoting a return to pure assertions of national sovereignty, populist government creates institutional structures in which both of the primary achievements of the global legal system - national democracy and nationhood itself - are visibly undermined. If analysed closely, populism appears as a regime type that effects a reversal of the sociological processes that are presupposed for the existence of sovereign states and sovereign peoples.

\section{Constitutional crisis and weak citizenship}

Some recent attempts to position the national sovereign people at the legitimational centre of the political system have led directly to constitutional crisis, eroding national systems of democratic representation. In such examples, the capacity of the political system to assume legitimacy through reference to national citizens as sovereign actors has been critically weakened.

A moderate example of this loss of attachment to citizens can currently be observed in the USA. In this context, legitimacy for government is generated through express emphasis on the will of national citizens, defined in antithesis to globally constructed norms. ${ }^{110}$ However, in this polity, instruments for the representation of national citizens in government have clearly been weakened. This is reflected in the fact that established political parties lose some of their ability to connect citizens to the political system, such that political communications partly by-pass routinized patterns of interest aggregation. This is more sharply reflected in the increasing importance of executive legislation, in which conventional processes for linking

\footnotetext{
110 See supra note 5.
} 
legislative procedures to representative bodies is diminished. ${ }^{111}$ A more acute example of such loss of attachment is Brazil, where the recent turn towards anti-globalist models of legitimacy has led both to the weakening of institutional procedures for citizenship practice and to the intensification of executive law-making. ${ }^{112}$ A still more extreme example is the case of Venezuela. Here, the constitution of 1999 sought to integrate the people as a live constituent power in the state. Ultimately, however, it created a mandate for an autonomous presidential executive, deeply reliant on legislation by decree. ${ }^{113}$ Perhaps the most distinctive example of this phenomenon can be observed in the UK. In this setting, opposition to the seeming loss of sovereignty by the UK parliament owing to its integration in the European Union and the European human rights system led to the organization of a referendum in 2016, supposedly to re-centre the political system, or the organs of parliament within the political system, more firmly around the popular sovereign will. However, this referendum had the outcome that a plebiscitary decision was taken outside parliament, supposedly by the national people in exercise of sovereignty, which became informally hyper-entrenched against the will of parliament itself. The result of this was that parliament, constitutionally the sovereign organ of the polity, forfeited its sovereignty, and lost power to discharge its mandate towards the people, for the sake of whose sovereignty the 2016 referendum had been called. This process led, not to increased direct representation, but to increased reliance on executive legislation. ${ }^{114}$ This shift to executive predominance has been checked in part by

\footnotetext{
111 Trump's reliance on executive orders is well documented.

112 P. Cerdeira et al, Congresso em números: a produção legislativa do Brasil de 1988 a 2017, http://bibliotecadigital.fgv.br/dspace/bitstream/handle/10438/24019/Congresso $\% 20 \mathrm{em} \% 20 \mathrm{n} \% \mathrm{C} 3 \% \mathrm{BAmeros} \% 2$ 02017\%20- $\% 20 \mathrm{a} \% 20$ produ $\% \mathrm{C} 3 \% \mathrm{~A} 7 \% \mathrm{C} 3 \% \mathrm{~A} 3 \mathrm{o} \% 20$ legislativa $\% 20 \mathrm{do} \% 20$ Brasil.pdf?sequence $=1 \&$ is Allowed $=\mathrm{y}$, at 20-21

113 M.J. Garcia-Serra, 'The "Enabling Law": The Demise of the Separation of Powers in Hugo Chavez's Venezuela', 32(2) University of Miami Inter-American Law Review (2001).

${ }^{114}$ For analysis of the use of executive legislation to implement Brexit see https://ukconstitutionallaw.org/2019/02/07/alexandra-sinclair-and-joe-tomlinson-deleting-the-administrativestate/.
} 
recent legal rulings, but such rulings underline the anxieties and constitutional uncertainties surrounding this uncharted process. ${ }^{115}$

In each instance, the heightened assertion that the national sovereign people must form the immediate basis for state action created a political order in which the capacity of the government to channel norms produced by citizens into legislation was diminished. In each case, governments have disrupted the procedures through which the interests of citizens establish foundations for legislation, and they have dramatically eroded the premises of national citizenship. To this degree, such governments have experienced a partial regression to pre-national conditions.

Failures of integration and social militarization

In some cases, the attempt to position the national sovereign people at the legitimational centre of the political system has undermined the basic integrational order of society, so that society as a whole forfeits, in part, its material quality as nation.

Such structural disintegration can be seen in the legal systems of polities with populist governments. As discussed, political systems whose legitimacy is defined by the rhetoric of sovereignty usually reduce the standing of judicial institutions, especially when such institutions are backed by global human rights norms. ${ }^{116}$ In many societies, as discussed, global human rights formed a normative foundation on which national institutions were able to extend their force into society, and to incorporate all citizens in a shared sovereign order. In consequence, the weakening of independent judicial power often undermines society's integrational structures. First, reduction of independent judicial authority frequently leads to a

\footnotetext{
115 See R (Miller) v The Prime Minister and Cherry v Advocate General for Scotland [2019] UKSC 41.

116 See supra notes 4-5.
} 
situation in which different social groups are accorded variable rights, such that rights are closely linked to socio-economic, political, or ethnic status. Very clear examples of this are evident in Hungary and, in far more extreme form, in Brazil, in which protections for minorities and vulnerable social groups have been reduced through the rise of neonationalism. ${ }^{117}$ Second, reduction of independent judicial authority frequently gives rise to a situation in which the legal mechanisms that subordinate geographically peripheral social groups to central state institutions are diminished, so that regional elites acquire accentuated power. This is especially evident in Brazil, where old oligarchical structures appear to be in the process of re-articulation. ${ }^{118}$ A probable result of these developments, third, is that local sources of authority will acquire renewed importance, and local elites will act as mediators between regional groups and national agencies. ${ }^{119}$ In such processes, the core function of global human rights in imprinting a national structure on society is diminished, and the legal system forfeits some of its capacity for linking diffuse agents and regions to the political system. As a result, the basic sovereignty of the state and the basic integrity of national citizenship are undermined.

Such structural disintegration can also be seen in the territorial dimension of societies with populist governments. A common feature of overtly nationalistic governance systems is that they rely for support on locally specific constituencies, and they generate compliance by mobilizing interests in certain regions against interests in other regions. This can be clearly seen in Brazil and Colombia, where voting tendencies are now deeply determined by regional identities. This can also be observed in the UK, where the territorial unity of national

\footnotetext{
117 Since 2017, anti-minority policies have been commonly reported by indigenous groups in Brazil. See details at http://apib.info/2017/04/07/organizacoes-alertam-alto-comissariado-da-onu-sobre-as-crescentes-ameacas-aosdireitos-indigenas-no-brasil/. See F.F. Bragato, 'Os caminhos do genocído indígena na atual política brasileira', at https://emporiododireito.com.br/leitura/os-caminhos-do-genocidio-indigena-na-atual-politica-brasileira (2019). 118 See supra note 112.

119 This is a classical feature of societies with low rights protection. See O. Oszlak, 'The Historical Formation of the State in Latin America: Some Theoretical and Methodological Guidelines for its Study', 16(2) Latin American Research Review (1981) 17.
} 
citizenship is exposed to severe duress as a result of the nationalist policies of the Conservative government.

Such structural disintegration is also visible in the fact that, in societies with populist governments, the capacity of political institutions to create laws for society as a whole is reduced. In particular, legislative institutions in neo-nationalist polities are often unable to rely on generally acceded norms to underpin legislation, and they are usually required to utilize informal means to implement legislation across society. For these reasons, such polities tend to require support from local elites to maintain legal compliance. ${ }^{120}$ In extreme cases, of course, the power of the state to enforce uniform legal norms across society depends on a remilitarization of the political order, in which the imposition of legal obligations hinges on the transformation of political institutions into military instruments. ${ }^{121}$

In each of these features, populist governance regimes mark a return to a pattern of politicalsystemic organization that characterizes incompletely nationalized societies, and it reverts to a moment in the history of nation building and citizenship construction in which state organs had not yet acquired full sovereignty.

High porosity of institutions to private actors

In some cases, the attempt to position the national sovereign people at the legitimational centre of the political system has disrupted the essential capacity of political institutions to exercise public authority. In particular, it reduces the distinction, fundamental to national

\footnotetext{
${ }^{120}$ In Colombia, for example, citizenship was historically linked to local attachments and mediated through local elites, and there is an acute danger that it will return to this form. See J. W. Márquez Estrada, 'De vecinos a ciudadanos. Las estrategias políticas y culturales en el proceso de formación de la ciudadanía en Colombia', 16 Anuario de Historia Regionaly de las Fronteras (2012).

121 The military has recently acquired renewed prominence in Venezuela and Brazil. One commentator sees Brazil now as a military state, in which the army is the 'main center of political power': A.A. Goldstein, 'The New FarRight in Brazil and the Construction of a Right-Wing Order', 46(4) Latin American Perspectives (2019) 251.
} 
society, between the political system and other centres of coercion, and it undermines the essential hierarchy between institutions backed by norms constructed through reference to the popular will and organizations or actors with subordinate authority.

First, polities that found their authority in national sovereignty tend, in factual practice, to weaken controls regulating access to political power and public office. This is usually the result of the diminution of judicial counterweights to political authority, but it is also linked to the fact that administrative procedures are less closely defined by human rights norms. In many populist states, government offices coalesce closely with elite privileges, such that public office and private resources are not easily separable. ${ }^{122}$ This is also the result of the fact that such polities rely on powerful private actors to generate political support, who then expect remuneration through distribution of offices. Second, as discussed, polities based in emphatic expressions of national sovereignty usually depend on informal intermediary actors to correlate central institutions with peripheral authorities. One reason for this is that, as they limit the purchase of overarching legal norms, they are required to sustain the transmission of law through society by more ad hoc arrangements, reliant on personalized accommodation. Consequently, leading figures in such polities often use patronage to hold together different tiers of the political system, and they routinely confer privilege and effective autonomy on local actors. ${ }^{123}$ In each of these respects, a polity that is emphatically based in national sovereignty often experiences a loss of autonomy in relation to other organizations and personalities, and it tends to trigger, or at least to bear witness to, a process of

\footnotetext{
122 M. López Maya, 'Venezuela: The Political Crisis of Post-Chavismo', 40(4) Social Justice (2014) 73. ${ }^{123}$ See M. Albertus, 'The Role of Subnational Politicians in Distributive Politics: Political Bias in Venezuela's Land Reform under Chávez', 48(13) Comparative Political Studies (2015) 1705. Recent months in Brazil have seen an increasingly uneven distribution of resources from the national government to the states, in which states that supported Bolsonaro, and elite leaders in these states, have received reward for political loyalty. See https:// noticias.uol.com.br/politica/eleicoes/2018/noticias/2018/10/29/falta-de-aliados-e-de-propostas-preocupanordeste-no-governo-bolsonaro.htm.
} 
denationalization, in which society's institutional order partly regresses to a pre-national form.

Overall, the institutional form of neo-nationalist government usually demonstrates that the preconditions of national democracy and national society itself are endangered, paradoxically, by governments that extract legitimacy from a simple construction of the sovereign national people. This fact provides evidence to support the first core claim above namely, that the sovereign nation is a political achievement, which is not easily created by members of the nation itself and is usually secured by global norms. This fact also provides evidence to support the second core claim above - that the literal constitutional diction of national democracy is based in a deep misunderstanding of both democracy and nationhood. This fact also implies that global norms did not simply underpin the rise of national democracy. On the contrary, they remain vitally implicated in the integration processes that sustain democracy, and these processes can easily be reversed wherever global norms lose influence.

\section{Conclusion}

National democracy and national society more widely are the results of precarious, counterintuitive processes of subject construction, institution building and national integration. Most importantly, these processes were not conducted, simply, by the subjects envisaged in classical theories of constitutional democracy - by sovereign peoples, nationally integrated societies, and sovereign political institutions. National democracy is not a social reality that pre-existed the global system of legal norms, and it is largely contingent on global patterns of norm construction. In contemporary society, however, the global reality of democracy is endlessly contradicted by the national subjects placed at the heart of democracy by 
constitutional theory. This contradiction creates a deep legitimational opportunity for neonationalist government.

The rise of neo-nationalism or populism is a distinctive constitutional feature of contemporary society, and it requires explanation as such. Generally, however, constitutional analyses of populism have failed adequately to explain populism. Such analyses have remained too uncritical in their discussion of constitutional democracy itself, and they have often promoted conceptual subjects that prevent them from understanding populism. As populism becomes a more unsettling phenomenon, a deep sociological reorientation in constitutional theory may be required. If it wishes to preserve democracy, constitutional analysis may need to state clearly that its own basic subjects are unreal, and that the underlying principles of constitutional democracy - sovereign peoples and sovereign national societies - cannot be obtained in simple form. Until such a moment, populism will indeed form a distinctive pattern of constitutionalism. 